\title{
SPRAWOZDANIA
}

\section{Konferencja naukowa „Refleksja w uczeniu się i nauczaniu języków obcych”, Wrocław 9-11 września 2013}

W dniach 9-11 września 2013 roku odbyła się kolejna konferencja naukowa Polskiego Towarzystwa Neofilologicznego. Organizatorami byli: Instytut Filologii Angielskiej Uniwersytetu Wrocławskiego oraz Wydział Nauk Humanistycznych i Społecznych Karkonoskiej Państwowej Szkoły Wyższej w Jeleniej Górze. Wzięło w niej udział około stu czterdziestu uczestników z różnych ośrodków naukowych w Polsce.

W pierwszym dniu konferencji na posiedzeniu plenarnym zostały wygłoszone dwa referaty. Stefania Walasek przedstawiła wykład na temat „Powinności nauczyciela” wiejskiego w XIX i na początku XX wieku, w którym omówiła zadania, zakres obowiązków i postawy wobec procesu dydaktycznego nauczycieli na przełomie XIX i XX wieku. Weronika Wilczyńska w swoim wystąpieniu zatytułowanym Myślenie automatyczne a myślenie refleksyjne, czyli o podejmowaniu decyzji językowych w J2 skupiła się na psychologicznych aspektach kontroli działań komunikacyjnych w J2, eksponując koncepcję umysłu w ujęciu D. Kahnemana.

W ciągu trzech dni konferencji obrady odbywały się w kilku sekcjach. Tematem wiodącym była refleksja jako pole badawcze glottodydaktyki. W sekcji „Techniki i narzędzia używane do pobudzenia refleksji” przedmiotem uwagi były zagadnienia dotyczące samooceny i kontroli wyników nauczania, wykorzystania protokołu głośnego myślenia $\mathrm{w}$ badaniach, coachingu jako metody wspierania procesu dydaktycznego, poradników metodycznych, zadań projektowych, wirtualnej klasy, badań biograficznych (Magdalena Witkowska Refleksja w działaniu - o wykorzystaniu protokołu głośnego myślenia (TAP) do pobudzania refleksji przyszłych nauczycieli języka angielskiego; Adrian Golis Samoocena i kontrola wyników nauczania uczniów klas 1-3 szkoły podstawowej na przykładzie języka angielskiego; Halina Wiśniewska Podejście coachingowe jako narzędzie służące rozwojowi reflek- 
sji w nauczaniu języków obcych; Ewa Andrzejewska Poradnik metodyczny jako narzędzie rozwijania refleksji nauczyciela języków obcych; Gabriela Gorąca-Sawczyk Zadania projektowe jako impuls do rozważań na temat poszerzania świadomości kulturowej na zajęciach z języka obcego; Wioletta Anna Piegzik Od refleksji do konstruowania wiedzy $i$ wspólnoty komunikacyjnej: wyniki badania w działaniu; Mariusz Kruk Refleksja w uczeniu się gramatyki na lekcjach języka angielskiego $z$ wykorzystaniem zasobów Internetu $i$ wirtualnego świata; Anna Jaroszewska Badania biograficzne jako źródło refleksji nad procesami nauczania/uczenia się języków obcych).

W sekcji „Refleksja osoby uczącej się” sporo uwagi poświęcono nauczaniu wymowy, uczniom uzdolnionym językowo oraz słabym, badaniom prowadzonym w szkolnictwie wyższym (Aleksandra Wach Wspomaganie refleksyjności $w$ procesie uczenia się wymowy języka angielskiego poprzez wykorzystanie technologii; Małgorzata Baran-Łucarz 'Musimy je pisać?', 'Ale po co?' - podejście studentów filologii angielskiej do pisania refleksji związanych z uczeniem się wymowy; Krzysztof Nerlicki Nauka języków obcych w poglądach uczących się: przegląd metod $i$ dotychczasowych wyników badań; Ewa Piechurska-Kuciel Poglady na naukę języka obcego u osób z wysoką i niską gotowością komunikacyjna w języku obcym uczniów; Weronika Markowska Refleksja w nauczaniu wymowy języka rosyjskiego: z punktu widzenia nauczyciela i studenta; Adriana Biedroń Zdolność do autorefleksji uczniów ponadprzeciętnie uzdolnionych językowo; Mirosława Anna Domińska Jak się uczyć? Pomoc słabszym uczniom; Marzanna Karolczuk Rola refleksji w przygotowaniu ucznia do komunikacji międzykulturowej na lekcji języka rosyjskiego (drugiego obcego); Izabela Bawej Język obcy jako obiekt refleksji na poziomie zaawansowanym - badania ankietowe).

Tematyka sekcji „Refleksja w europejskiej polityce językowej” znalazła odzwierciedlenie w następujących prezentacjach: Iwona Janowska Refleksyjność $w$ świetle tekstów Europejskiego systemu opisu kształcenia językowego; Magdalena Urbaniak Europejskie portfolio dla studentów - przyszłych nauczycieli języków jako narzędzie wspierające refleksję w procesie kształcenia nauczycieli; Małgorzata Jedynak Działania Unii Europejskiej a rozwijanie refleksji nad procesem uczenia sie $i$ nauczania języka obcego; Liliana Szczuka-Dorna Rola i potrzeba refleksji $w$ dokumentach Rady Europy i Unii Europejskiej, dotyczacych nauczania i uczenia się języków obcych.

Referenci poruszali się również w kręgu zagadnień związanych z osobą (przyszłego) nauczyciela. W sekcji „Refleksja nauczyciela” badania omówili: Magdalena Białek Refleksje nauczycieli jako podstawa identyfikacji i analizy ich potrzeb szkoleniowych; Anna Buczko Samoocena jako integralna część refleksyjnej praktyki nauczyciela języków obcych; Dorota Werbińska Uczenie się z biografii zawodowej: Refleksje autobiograficzne emerytowanych nauczycielek języka obcego; 
Nina Barłożek Refleksja nad znaczeniem inteligencji emocjonalnej w zawodzie nauczyciela; Anna Pol Refleksyjność jako kluczowa cecha kompetentnego nauczyciela języka obcego. Natomiast w sekcji „Refleksja studenta-przyszłego nauczyciela” referaty prezentowali: Halina Widła Miejsce na refleksje przyszłych nauczycieli $w$ dobie nowych technologii; Tomasz Róg Praktyk oczami praktykanta; Zofia Chłopek Student tuż przed licencjatem - refleksyjny czy odtwórczy?; Iwona Dronia Refleksja w nauczaniu gramatyki praktycznej studentów filologii angielskiej niezbędnym komponentem rozwoju kompetencji metodycznej nauczyciela; Hadrian Lankiewicz Wykorzystanie form rozmowy (poszukującej i krytycznej) jako refleksji na temat konstrukcjonistycznej natury wiedzy i języka.

Badania obejmujące interdyscyplinarność zajęć w klasie językowej, rozwijanie świadomości ucznia, perspektywy kształcenia zawodowego, testowanie uczniów, proces nauczania i uczenia się języka japońskiego, uwarunkowania osobowościowe ucznia, psychologię pozytywną, treści kształcenia, zjawisko bilingwizmu nienatywnego były przedmiotem uwagi w sekcji „Nowe podejścia w glottodydaktyce" (Bernadeta Wojciechowska Refleksja nad warstwa implicytna wypowiedzi $w$ procesie rozwijania kompetencji rozumienia radiowego dyskursu publicystycznego; Agnieszka Kościńska Nowe wyzwania i perspektywy w kształceniu zawodowym - przygotowanie nauczycieli języka obcego do nauczania języka obcego zawodowego; Katarzyna Kwiek MBTI czyli wskaźnik psychologiczny Myersa-Briggsa a wybór drogi zawodowej studentów romanistyki; Jacek Rysiewicz Tzw.'testy predyspozycji językowych' do gimnazjum sa szkodliwe społecznie; Krzysztof Olszewski Refleksja leksykografa - o trudnościach w pracy ze słownikami języka japońskiego i metodach ich pokonywania; Joanna Wypusz Koncepcja DaFnE w Polsce - konieczność czy mrzonka?; Bartłomiej Drozd Badania terenowe a refleksja badacza kultury, czyli jak poznać kulturę danej społeczności; Maciej Smuk Savoir-être: wyzwanie epistemologiczne; Sonia Szramek-Karcz Refleksja nad bilingwizmem nienatywnym (NNB) w Polsce).

W ramach sekcji „Refleksja w edukacji” referaty wygłosili: Lech Zabor, Agnieszka Rychlewska Zdolność ucznia do podejmowania refleksji w procesie poprawy błędów w języku mówionym; Sabina Nowak „Ta kartka na mnie patrzy” czyli o refleksji oczami uczacych się; Magdalena Wawrzyniak-Śliwska Refleksja studentów studiów filologicznych - zaniedbania, opór i pozorowanie refleksji; Kamila Ciepiela Refleksja jako czynnik identyfikujacy we wspólnocie praktyków.

W konferencji wzięli też udział badacze strategii uczenia się w zakresie rozwijania sprawności rozumienia ze słuchu, przyswajania leksyki oraz podsystemu gramatycznego i ortograficznego języka obcego. W sekcji „Rola strategii uczenia się" wystąpili: Mirosław Pawlak Użycie strategii uczenia się podczas wykonywania ćwiczeń gramatycznych: Wyniki badań; Anna Sulikowska Rola strategii pamięciowych w sterowanej akwizycji języka obcego; Mieczysław Gajos Strategie kognitywne 
$w$ przyswajaniu relacji fonogramicznych w języku francuskim; Adriana Prizel-Kania Podejście strategiczne do nauczania sprawności rozumienia ze słuchu; Aleksandra Chirkowska, Marcelina Kałasznik Nauczanie akademickie z punktu widzenia doktorantów - Analiza refleksji i „strategii” nauczania młodych naukowców.

Problemy badawcze podejmujące zagadnienia kulturowe w sekcji „Świadomość (inter)kulturowa” omówili: Krystyna Mihułka "Nie lubię Niemców, bo nie” - o autorefleksji w postrzeganiu innych oraz Adam Jarosz O wymuszonej refleksji czyli o (nie)obecności nowych modeli rodziny w nauczaniu języka francuskiego $w$ Polsce.

W innych wystąpieniach skupiono się na kształceniu studentów. W sekcji „Kształcenie w szkolnictwie wyższym” referaty wygłosili: Sabina Nowak Rola refleksji i samooceny w rozwijaniu zintegrowanych umiejętności językowo-przedmiotowych w szkole wyższej - doniesienie naukowe; Przemysław Wolski Przedsiębiorczość w przygotowaniu nauczyciela języka obcego do zawodu. Natomiast w sekcji "Kształcenie akademickie i specjalistyczne” badania prezentowali: Katarzyna Molek-Kozakowska Dyspozycja krytyczna jako kompetencja akademicka; Anna Małgorzewicz Refleksja w dydaktyce przekładu; Iwona Gajewska-Skrzypczak Język specjalistyczny - wyzwaniem dla nauczyciela i studenta?

W kolejnym bloku referatów wygłoszonych w sekcji „Refleksja w pedagogice ogólnej i glottodydaktyce" poruszono zagadnienia związane z różnymi aspektami badań w zakresie kształcenia osób dorosłych (Krystyna Droździał-Szelest Miejsce i rola refleksji $w$ nauczaniu języków obcych $z$ punktu widzenia stuchaczy studiów podyplomowych na neofilologii; Elżbieta Gajewska, Magdalena Sowa Refleksyjna praktyka w nauczaniu języka specjalistycznego; Dorota Pudo Rola refleksji w nauczaniu dorostych stuchaczy komercyjnych kursów językowych; Agnieszka Kubiczek Świadomość glottodydaktyczna jako cel kształcenia nauczycieli języków obcych).

W sekcji „Rola oceniania w glottodydaktyce” referaty prezentujące problematykę samokontroli w procesie uczenia się języka obcego oraz konstruowaniu zadań egzaminacyjnych wygłosili: Urszula Paprocka-Piotrowska Autokorekta $w$ wypowiedziach obcojęzycznych. O zdolności refleksji i samooceny; Radosław Kucharczyk Jak definiować poprawność językowa w epoce wielojęzyczności? Kryteria oceny ustnego egzaminu maturalnego z języka obcego nowożytnego.

W sekcji „Rozwijanie kompetencji komunikacyjnej” badania zaprezentowali: Joanna Górecka Rozwijanie i ocenianie kompetencji komunikacyjnej w interakcjach online: wypracowywanie siatek oceny dla zadania dyskusji; Agnieszka Nowicka Działania metakomunikacyjne $w$ rozwijaniu kompetencji komunikacyjnej w JO; Liliana Piasecka Tekst literacki w nauce języków obcych; Olga Majchrzak Dzienniki a rozwijanie umiejętności pisania w języku obcym. 
Drugiego dnia konferencji odbył się Walny Zjazd PTN. Wybrany został nowy Zarząd na lata 2013-2016. Przewodniczącym Polskiego Towarzystwa Neofilologicznego został prof. dr hab. Mirosław Pawlak. Tego samego dnia interesujący referat plenarny na temat Możliwości wykształcenia refleksyjnych uczniów przez refleksyjnych nauczycieli wygłosiła Maria Wysocka.

W trakcie konferencji odbyły się również ciekawe warsztaty dotyczące technik przekładu, sposobów rozwijania sprawności pisania, kompetencji kulturowych oraz wykorzystania tekstów poetyckich na lekcji języków obcych.

Konferencję zamknęły dwa wystąpienia plenarne. Elżbieta Zawadzka-Bartnik wygłosiła referat zatytułowany Refleksja w zawodzie nauczyciela - założenia a realne możliwości realizacji, natomiast Anna Niżegorodcew podjęła ważne rozważania na temat kształcenia akademickiego (Pomiędzy autonomia a standaryzacją: krytyczne spojrzenie na tzw. efekty kształcenia w programach studiów neofilologicznych).

Konferencyjnym obradom towarzyszyły imprezy kulturalne: występ Zespołu Tańca Dawnego Uniwersytetu Wrocławskiego oraz zwiedzanie i poznawanie historii Wrocławia zabytkowym tramwajem.

Warto podkreślić dobrą organizację konferencji. Formuła, umożliwiająca zmianę sekcji po każdej prezentacji, pozwoliła uczestnikom na swobodny wybór referatów.

Spotkanie prelegentów z różnych ośrodków naukowych stało się okazją do podzielenia się doświadczeniami oraz najnowszymi badaniami z zakresu glottodydaktyki.

Marzanna Karolczuk

Białystok 